\title{
Genetic Distances of Three White Clam (Meretrix lusoria) Populations Investigated by PCR Analysis
}

\author{
Dae-Hyun Kim and ${ }^{\dagger} J o n g-M a n$ Yoon \\ Department of Aquatic Life Medicine, College of Ocean Science and Technology, \\ Kunsan National University, Gunsan 573-701, Republic of Korea
}

\begin{abstract}
The twenty-one individuals of Meretrix lusoria were secured from Gunsan, Shinan and Yeonggwang on the coast of the Yellow Sea and the southern sea in the Korean Peninsula, respectively. Amplification of a single COI fragment (720 bp) was imagined, and no apparent size differences were observed in amplified fragments between Meretrix lusoria and M. petechialis individuals. The size of the DNA fragments also varied excitedly, from 200 to 1,600 bp. The oligonucleotides primer BION-08 produced the least loci (a total of 17), with an average of 2.43 in the Gunsan population, in comparison to the other primers used. Remarkably, the primer BION-13 detected 42 shared loci by the three populations, major and/or minor fragments of sizes $200 \mathrm{bp}$ and $400 \mathrm{bp}$, respectively, which were identical in all samples. The dendrogram gained by the seven oligonucleotides primers highlight three genetic clusters: cluster 1 (GUNSAN $01 \sim$ GUNSAN 07), cluster 2 (SHINAN $08 \sim$ SHINAN 14) and cluster 3 (YEONGGWANG $15 \sim$ YEONGGWANG 21). The longest genetic distance among the twentyone Meretrix lusoria individuals that displayed significant molecular differences was between individuals GUNSAN no. 01 and SHINAN no. 14 (genetic distance $=0.574$ ). Comparatively, individuals of SHINAN population were fairly closely related to that of YEONGGWANG population. In this study, PCR analysis has discovered significant genetic distances between two white clam population pairs $(P<0.05)$.
\end{abstract}

Key words : Genetic cluster, Genetic distance, Hierarchical dendrogram, Meretrix lusoria, Veneridae, White clam

\section{INTRODUCTION}

Asian white clams (Meretrix lusoria) is commercially important bivalves, belonging to family Veneridae, widely distributed on the coast of the Yellow Sea, the southern sea and Jeju island in the Korean Peninsula and the several sea areas in China under the natural ecosystem (Min et al., 2004). Meretrix is widely distributed in the sandy tidal flat, the intertidal zone and 20-meter depth of seawater areas.
Generally, Meretrix petechialis can be easily distinguished from $M$. lusoria by morphology, with the posterior dorsal margin of $M$. lusoria being straight, while that of $M$. petechialis is quite swollen, and the apex position of $M$. lusoria is skewed to the anterior side relative to that of $M$. petechialis (Yamakawa \& Imai, 2012). But, juveniles of $M$. lusoria and M. petechialis have very similar morphologies and shell colors, making species identification difficult at the juvenile stage. Currently, DNA-based techniques for

\footnotetext{
Manuscript received 3 April 2014, Received in revised form 17 April 2014, Accepted 30 April 2014

${ }^{\dagger}$ Corresponding Author : Jong-Man Yoon, Department of Aquatic Life Medicine, College of Ocean Science and Technology, Kunsan National University, Gunsan 573-701, Korea. Tel. : +82-63-469-1887, Fax : +82-63-463-9493, E-mail : jmyoon@kunsan.ac.kr

This is an Open Access article distributed under the terms of the Creative Commons Attribution Non-Commercial License (http:// creativecommons.org/licenses/by-nc/3.0) which permits unrestricted non-commercial use, distribution, and reproduction in any medium, provided the original work is properly cited.
} 
identifying interspecific variation have been established and applied to some bivalve species, including closely related species belonging to the same Genus. Studies on molecular phylogeny of Veneridae were reported genetic relationship of Veneridae five species (Jung et al., 2004), were announced using mitochondrial 16S rRNA gene or cytochrome oxidase sequencing (Chen et al., 2009). But, no studies have tested for the identification of $M$. lusoria and M. petechialis in some Korean localities.

In the present study, to elucidate characteristics of individuals and populations by identifying the genetic distances and geographical variations among three white clam (Meretrix lusoria) populations collected from Gunsan, Shinan and Yeonggwang, we performed a clustering analysis by using PCR method and Systat pc-package program.

\section{MATERIALS AND METHODS}

\section{Sample collection and purification of genomic DNA}

The twenty-one individuals of Meretrix lusoria were secured from Gunsan, Shinan and Yeonggwang on the coast of the Yellow Sea and the southern sea in the Korean Peninsula, respectively (Fig. 1). Muscle tissues was collected in sterile tubes and stored at $-40^{\circ} \mathrm{C}$ until needed. DNA extraction should be carried out according to the separation and extraction methods (Yoon and Kim, 2004). The precipitates obtained were then centrifuged and resuspended in lysis buffer II (10 mM Tris-HCl, pH 8.0; 10 mM EDTA; $100 \mathrm{mM} \mathrm{NaCl} ; 0.5 \%$ SDS), and $15 \mu \mathrm{L}$ of proteinase $\mathrm{K}$ solution $(10 \mathrm{mg} / \mathrm{mL})$ was added. After incubation, we added $300 \mu \mathrm{L}$ of $3 \mathrm{M} \mathrm{NaCl}$, and gently pipetted for a few minutes. $600 \mu \mathrm{L}$ of chloroform was then added to the mixture and inverted (no phenol). Ice-cold 70\% ethanol was added, and then the samples were centrifuged at $19,621 \mathrm{~g}$ for 5 minutes to extract the DNA from the lysates.

\section{Mitochondrial DNA extraction}
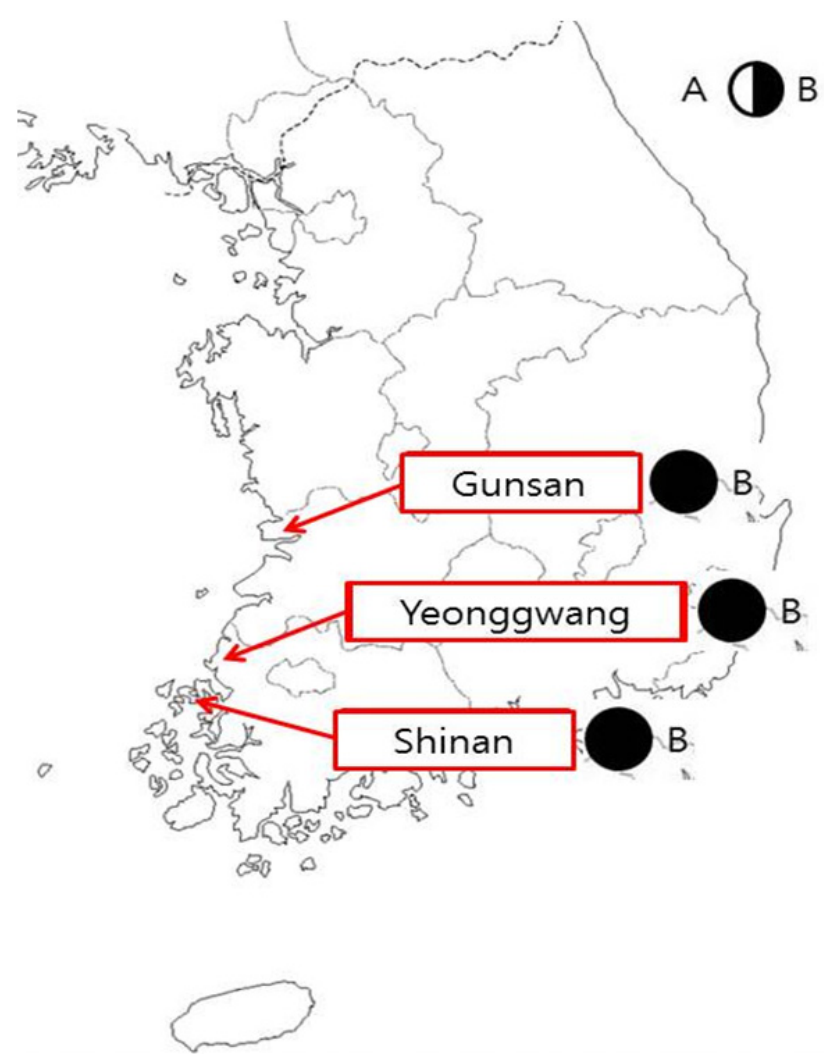

Fig. 1. Map illustrating bivalve sampling regions. Genomic DNA and mitochondrial DNA samples isolated from three geographical Meretrix lusoria populations in Gunsan, Shinan and Yeonggwang collected in the sea, off the Korean Peninsula. Hinc II restriction type (A and B) frequencies of three different provinces in Korea. Type A indicates Meretrix petechialis individuals and type B indicates M. lusoria individuals. Numbers alongside the pie graph represent population numbers.

Muscle was collected in sterile tubes, washed with PBS (155 $\mathrm{mM} \mathrm{NH}_{4} \mathrm{Cl}, 10 \mathrm{mM} \mathrm{KHCO} 31 \mathrm{mM}$ EDTA) was added to the samples. Homogenize the muscle tissue and centrifuge at $740 \mathrm{~g}$ for $5 \mathrm{~min}$. Collect the supernatant and discard the pellet and centrifuge again at $740 \mathrm{~g}$ for $5 \mathrm{~min}$. Collect the supernatant, discard the pellet and centrifuge at $9,000 \mathrm{~g}$ for $10 \mathrm{~min}$. Discard the supernatant and gently resuspend the pellet containing mitochondria. Centrifuge mitochondrial suspension at $10,000 \mathrm{~g}$ for $10 \mathrm{~min}$. Remove the supernatant and gently resuspend the crude mitochon- 
drial pellet. Centrifuge mitochondrial suspension again $10,000 \mathrm{~g}$ for $10 \mathrm{~min}$ to remove any microsomal contamination. Get rid of the supernatant and resuspend the crude mitochondrial pellet. The crude mitochondrial pellet should be carried out according to the separation and extraction methods (Wieckowski et al. 2009). Mitochondrial DNA of crude mitochondrial pellet was extracted using a DNA blood and tissue kit (Qiagen GmbH, Duesseldorf, Germany).

\section{Mitochondrial DNA assay}

Mitochondrial DNA analysis was performed on the muscle extract of 30 individuals using specific primer. 720 bp fragment of the mitochondrial cytochrome $c$ oxidase subunit I (COI) was amplified by PCR using Thermal cyclers (MJ Research, Inc., Watertown, USA; Perkin Elmer Cetus, Norwalk, USA). PCR reaction was performed in 25 $\mu \mathrm{L}$ samples, which contained $2 \mu \mathrm{L}$ of template DNA, 20 $\mu \mathrm{L}$ of premix (Bioneer Corp., Daejeon, Korea), and $1 \mu \mathrm{L}$ each of $25 \mathrm{pM}$ primers (Forward : 5'-GGT CAA CAA ATC ATA AAG ATA TTG G-3' and Reverse : 5'-TAA ACT TCA GGG TGA CCA AAA AAT CA-3'; Folmer et al., 1994). This premix was followed a pre-denaturation at $94^{\circ} \mathrm{C}$ for $2 \mathrm{~min}$. The thermal cycler programmed for 30 cycles of denaturation at $94^{\circ} \mathrm{C}$ for $15 \mathrm{sec}$, annealing at $50^{\circ} \mathrm{C}$ for $15 \mathrm{sec}$, extension at $72^{\circ} \mathrm{C}$ for $30 \mathrm{sec}$, post-extension at $72^{\circ} \mathrm{C}$ for $7 \mathrm{~min}$.

RFLP surveys of the COI region indicated that Hinc II (Takara, Inc., Shiga, Japan) digestion produced heterogeneous distributions of restriction types among samples. RFLP analysis was performed in $20 \mu \mathrm{L}$ volume containing $2 \mu \mathrm{L}$ 10XM buffer (Takara, Inc., Shiga, Japan), $1 \mu \mathrm{L}$ of Hinc II and $6 \mu \mathrm{L}$ of PCR product at $37^{\circ} \mathrm{C}$ for $2 \mathrm{~h}$. A $20 \mu \mathrm{L}$ portion of the reactant was generated electrophoresis on $1 \%$ agarose (VentechBio, Eumsung, Korea) gel containing TBE (90 $\mathrm{mM}$ Tris, $\mathrm{pH}$ 8.5; $90 \mathrm{mM}$ borate; $2.5 \mathrm{mM}$ EDTA). Gels were stained with ethidium bromide, illuminated by ultra- violet rays, and photographed.

4. Oligonucleotides primers, molecular markers, amplification conditions and data analysis

Seven oligonucleotides primers BION-01 (5'-CAGGC CCTTC-3'), BION-08 (5'-TCCGCTCTGG-3'), BION-13 (5'-GTTTCGCTCC-3'), BION-17 (5'-TGCTCTGCCC-3'), BION-47 (5'-CAGCACCCAC-3'), BION-49 (5'-CGGTGG CGAA-3') BION-69 (5'-GCATCCACCA-3') were shown to generate average loci per lane and specific loci which could be clearly scored. Thus, the authors used the primers to study the genetic variations and DNA polymorphisms of the Meretrix lusoria. PCR was performed using two Programmable DNA Thermal Cyclers (MJ Research, Inc., Watertown, USA; Perkin Elmer Cetus, Norwalk, USA). PCR conditions was preheating at $94^{\circ} \mathrm{C}$ for 5 min followed by 45 cycles of denaturation at $94^{\circ} \mathrm{C}$ for $1 \mathrm{~min}$, annealing at $36^{\circ} \mathrm{C}$ for $1 \mathrm{~min}$, and extension at $72^{\circ} \mathrm{C}$ for $1 \mathrm{~min}$, and then a post-cycle extension at $72^{\circ} \mathrm{C}$ for $5 \mathrm{~min}$, using the fastest available transition between each temperature. Optimal DNA concentrations for amplification were determined by testing several dilutions, one of which was taken as the standard for every subsequent amplification. Amplification products were generated via electrophoresis on $1.4 \%$ agarose (VentechBio, Eumsung, Korea) gel containing TBE (90 mM Tris, pH 8.5; 90 mM borate; 2.5 mM EDTA). The 100 bp DNA Ladder (Bioneer Corp., Daejeon, Korea) was used as a DNA molecular weight marker. Bands were detected by ethidium bromide staining. The stained agarose gels were illuminated by ultraviolet rays, and photographed using a photoman direct copy system (PECA Products, Beloit, WI, USA).

The degree of variability was calculated by use of the Dice coefficient $(F)$, which is given by the formula: $F=2$ $\mathrm{n}_{\mathrm{ab}} /\left(\mathrm{n}_{\mathrm{a}}+\mathrm{n}_{\mathrm{b}}\right)$, where $\mathrm{n}_{\mathrm{ab}}$ is the number of bands shared between the samples $a$ and $b, n_{a}$ is the total number of bands for sample $a$ and $n_{b}$ is the total number of bands for 
sample b (Jeffreys \& Morton, 1987; Yoke-Kqueen \& Radu, 2006). Euclidean genetic distances within- and betweenpopulations were also calculated using the hierarchical dendrogram program Systat ver.10 (SPSS Inc., Chicago, IL, USA).

\section{RESULTS AND DISCUSSION}

\section{Mitochondrial DNA assay}

Amplification of a single COI fragment (720 bp) was imagined, and no apparent size differences were observed in amplified fragments between Meretrix lusoria and $M$. petechialis individuals. Hinc II digestion of PCR products discovered two unique restriction patterns designated type A (418 bp and 306 bp fragments) and type B (479 and 247 bp), that were completely diagnostic to distinguish $M$. lusoria from M. petechialis individuals (Yamakawa \& Imai, 2012). But no one of the three populations sampled in Korea contained $M$. petechialis restriction type A phenotype (Table 1 and Fig. 2). In general, the adult shell shape of M. lusoria is a curved triangle, while that of $M$. petechialis is elliptical. The caudal dorsal edge of $M$. lusoria is straight, whereas that of M. petechialis is puffy, and the top position of $M$. lusoria is slanted to the front side relative to that of $M$. petechialis (Min et al., 2004). Identifying Meretrix lusoria based only on morphological

Table 1. Collected Meretrix lusoria samples

\begin{tabular}{cccc}
\hline \multirow{2}{*}{ Location } & No. & \multicolumn{2}{c}{ Hinc II restriction type } \\
\cline { 3 - 4 } & & A & B \\
\hline GS & 10 & 0 & 10 \\
SA & 10 & 0 & 10 \\
YG & 10 & 0 & 10 \\
\hline
\end{tabular}

Frequencies of Hinc II restriction types of the mitochondrial DNA cytochrome c oxidase subunit I.

GS: Gunsan, SA: Shinan, YG: Yeonggwang

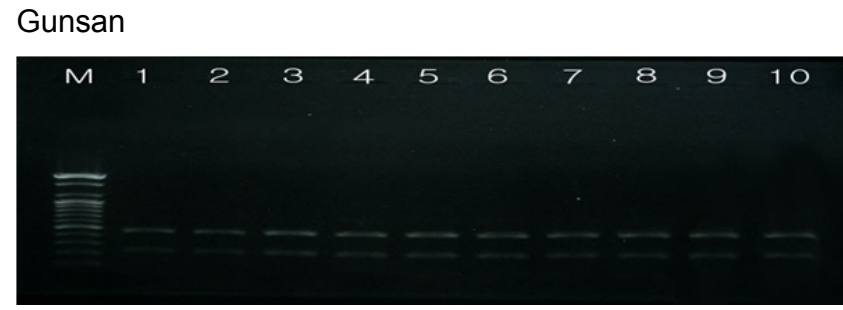

Shinan

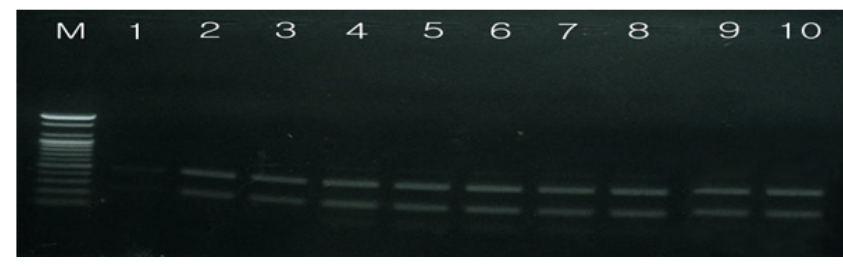

Yeonggwang

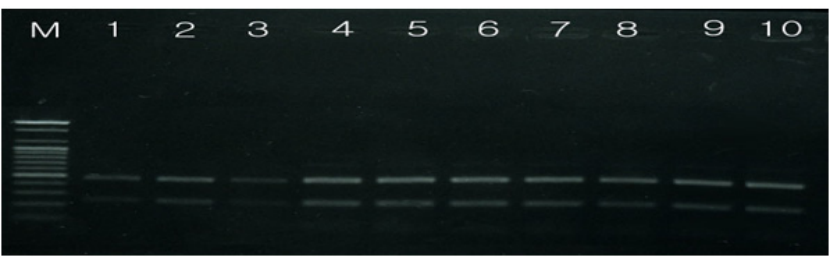

Fig. 2. The Hinc II restriction types of mitochondrial DNA cytochrome $c$ oxidase subunit I were separated by $1 \%$ agarose gel electrophoresis and detected by ethidium bromide staining. Molecular weight size (M) is shown along the left margin.

shell shape can be difficult while judgments based on a combination of morphology and genetic information is generally more trustworthy.

\section{Data analysis}

The amplified products were separated by agarose gel electrophoresis with oligonucleotides primers, and stained with ethidium bromide. Similarity matrix including bandsharing values (BS) and genetic differences was calculated using Nei and Li's index of the similarity of venerid clam individuals from Gunsan, Shinan and Yeonggwang of the Korean Peninsula, respectively, as illustrated in Table 2. The seven oligonucleotides primers BION-01, BION-08, BION-13, BION-17, BION-47, BION-49 and BION-69 generated the total number of loci, average number of loci per lane and specific loci in Gunsan, Shinan and Yeonggwang 
Table 2. Similarity matrix including bandsharing values (BS) and genetic differences calculated using Nei and Li's index of the similarity of Meretrix lusoria from Gunsan, Shinan and Yeonggwang of the Korean Peninsula, respectively

\begin{tabular}{|c|c|c|c|c|c|c|c|c|c|c|c|c|c|c|c|c|c|c|c|c|c|}
\hline \multicolumn{8}{|c|}{ BS from Gunsan } & \multicolumn{7}{|c|}{ BS from Shinan } & \multicolumn{7}{|c|}{ BS from Yeonggwang } \\
\hline & 1 & 2 & 3 & 4 & 5 & 6 & 7 & 8 & 9 & 10 & 11 & 12 & 13 & 14 & 15 & 16 & 17 & 18 & 19 & 20 & 21 \\
\hline 1 & - & 0.710 & 0.545 & 0.543 & 0.640 & 0.622 & 0.651 & 0.501 & 0.533 & 0.458 & 0.505 & 0.525 & 0.523 & 0.510 & 0.543 & 0.481 & 0.459 & 0.426 & 0.452 & 0.433 & 0.476 \\
\hline 2 & & - & 0.649 & 0.559 & 0.695 & 0.646 & 0.574 & 0.599 & 0.602 & 0.544 & 0.572 & 0.571 & 0.581 & 0.544 & 0.570 & 0.509 & 0.499 & 0.495 & 0.468 & 0.465 & 0.533 \\
\hline 3 & & & - & 0.574 & 0.592 & 0.566 & 0.509 & 0.429 & 0.436 & 0.408 & 0.372 & 0.433 & 0.413 & 0.376 & 0.477 & 0.452 & 0.447 & 0.416 & 0.395 & 0.460 & 0.386 \\
\hline 4 & & & & - & 0.591 & 0.722 & 0.697 & 0.535 & 0.507 & 0.453 & 0.481 & 0.482 & 0.473 & 0.481 & 0.543 & 0.544 & 0.509 & 0.538 & 0.507 & 0.475 & 0.499 \\
\hline 5 & & & & & - & 0.697 & 0.702 & 0.553 & 0.543 & 0.455 & 0.531 & 0.527 & 0.543 & 0.508 & 0.514 & 0.469 & 0.469 & 0.483 & 0.453 & 0.453 & 0.437 \\
\hline 6 & & & & & & - & 0.666 & 0.472 & 0.452 & 0.374 & 0.433 & 0.462 & 0.473 & 0.440 & 0.520 & 0.481 & 0.484 & 0.470 & 0.472 & 0.486 & 0.469 \\
\hline 7 & & & & & & & - & 0.480 & 0.513 & 0.450 & 0.461 & 0.491 & 0.510 & 0.516 & 0.466 & 0.476 & 0.512 & 0.517 & 0.552 & 0.501 & 0.471 \\
\hline 8 & & & & & & & & - & 0.913 & 0.867 & 0.852 & 0.746 & 0.783 & 0.790 & 0.698 & 0.594 & 0.678 & 0.665 & 0.586 & 0.544 & 0.618 \\
\hline 9 & & & & & & & & & - & 0.867 & 0.803 & 0.752 & 0.735 & 0.736 & 0.646 & 0.548 & 0.601 & 0.667 & 0.620 & 0.523 & 0.622 \\
\hline 10 & & & & & & & & & & - & 0.820 & 0.731 & 0.723 & 0.725 & 0.633 & 0.521 & 0.547 & 0.644 & 0.607 & 0.518 & 0.573 \\
\hline 11 & & & & & & & & & & & - & 0.853 & 0.865 & 0.818 & 0.750 & 0.662 & 0.655 & 0.704 & 0.694 & 0.563 & 0.660 \\
\hline 12 & & & & & & & & & & & & - & 0.887 & 0.840 & 0.721 & 0.641 & 0.681 & 0.688 & 0.634 & 0.569 & 0.641 \\
\hline 13 & & & & & & & & & & & & & - & 0.918 & 0.782 & 0.759 & 0.721 & 0.734 & 0.713 & 0.645 & 0.674 \\
\hline 14 & & & & & & & & & & & & & & - & 0.813 & 0.730 & 0.718 & 0.760 & 0.713 & 0.614 & 0.693 \\
\hline 15 & & & & & & & & & & & & & & & - & 0.780 & 0.722 & 0.720 & 0.682 & 0.618 & 0.675 \\
\hline 16 & & & & & & & & & & & & & & & & - & 0.820 & 0.725 & 0.696 & 0.780 & 0.650 \\
\hline 17 & & & & & & & & & & & & & & & & & - & 0.828 & 0.783 & 0.701 & 0.760 \\
\hline 18 & & & & & & & & & & & & & & & & & & - & 0.815 & 0.652 & 0.751 \\
\hline 19 & & & & & & & & & & & & & & & & & & & - & 0.662 & 0.815 \\
\hline 20 & & & & & & & & & & & & & & & & & & & & - & 0.663 \\
\hline 21 & & & & & & & & & & & & & & & & & & & & & - \\
\hline
\end{tabular}

population, as summarized in Table 3. Here, the complexity of the banding patterns varied dramatically between the primers from the three populations. The size of the DNA fragments also varied excitedly, from 200 to $1,600 \mathrm{bp}$, as shown in Fig. 3. The primer BION-01 generated the most loci (a total of 58), with an average of 8.29 in the Shinan population, as revealed in Table 3. The oligonucleotides primer BION-08 produced the least loci (a total of 17), with an average of 2.43 in the Gunsan population, in comparison to the other primers used. In this study, 7 primers generated 34.7 specific loci in the Gunsan population, 42.6 in the Shinan population and 40.1 in the Yeonggwang population. The specific loci generated by oligonucleotides primers demonstrated inter-individualspecific characteristics, thus revealing DNA polymorphisms. Many researchers considered the sizes of DNA fragments 


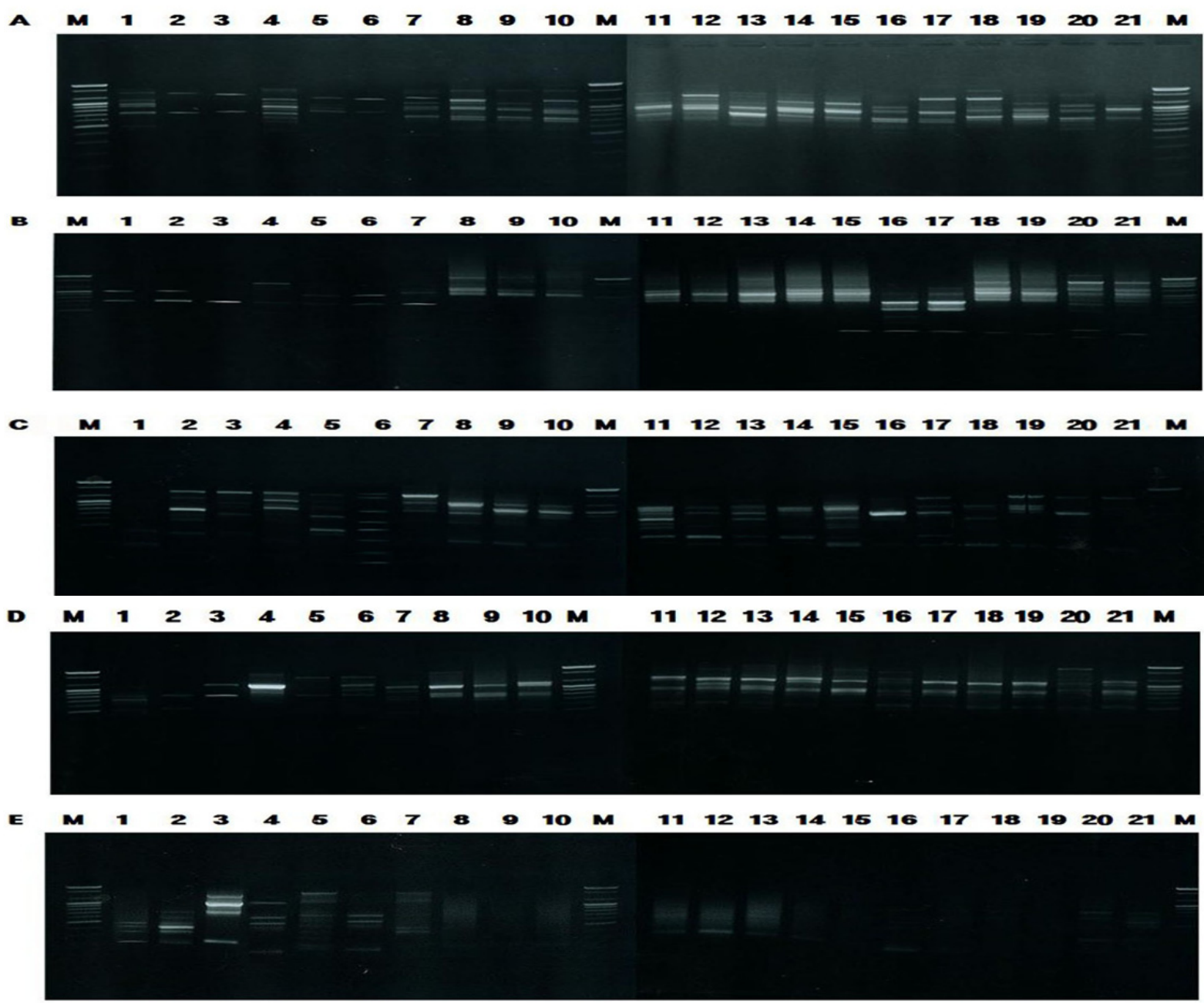

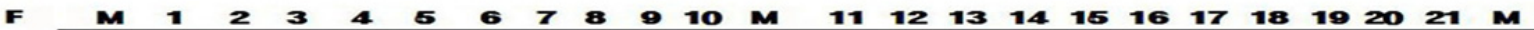

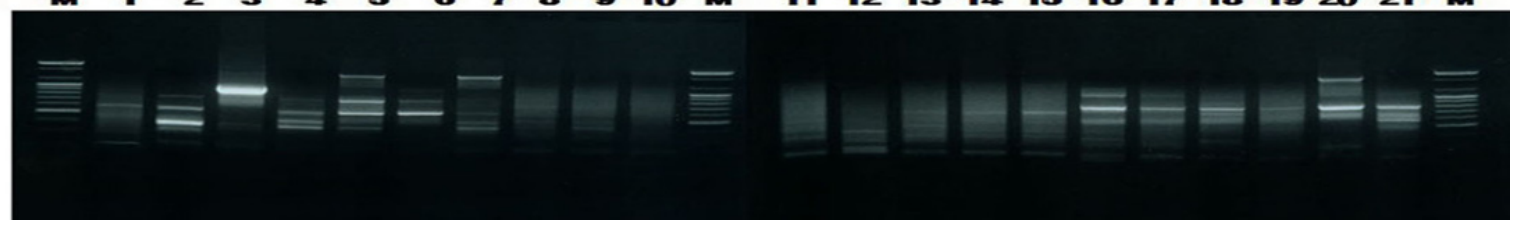

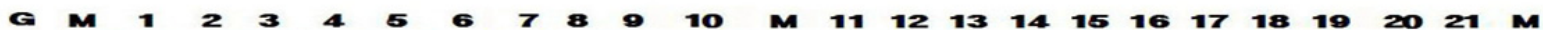

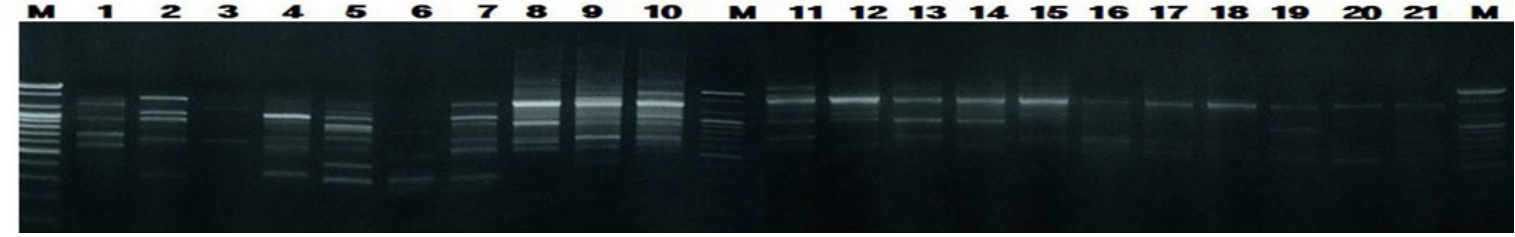

Fig. 3. PCR-based electrophoretic profiles of individuals Meretrix lusoria. DNA isolated from Gunsan population (lane $1 \sim 7$ ), Shinan population (lane $8 \sim 14$ ) and Yeonggwang population of Meretrix lusoria (lane $15 \sim 21$ ) were amplified by oligonucleotides decamer primers BION-1 (A), BION-8 (B), BION-13 (C), BION-17 (D), BION-47 (E), BION-49 (F) and BION-69 (G). The PCR products were divided by $1.4 \%$ agarose gel electrophoresis and detected by ethidium bromide staining. Each lane displays DNA samples extracted from 21 individuals. $100 \mathrm{bp}$ ladder was used as a DNA molecular size maker (M). 
Table 3. The number of total loci, average loci per lane, specific loci by PCR analysis using 7 decamer primers in Meretrix lusoria in Gunsan, Shinan and Yeonggwang of Korea

\begin{tabular}{|c|c|c|c|c|c|c|}
\hline \multirow{2}{*}{$\begin{array}{c}\text { Item } \\
\text { Primer }\end{array}$} & \multicolumn{3}{|c|}{ No. of average loci per lane } & \multicolumn{3}{|c|}{ No. of specific loci } \\
\hline & GS & $\mathrm{SA}$ & $\mathrm{YG}$ & GS & SA & YG \\
\hline BION - 01 & $\begin{array}{l}4.14 \\
(29)\end{array}$ & $\begin{array}{l}8.29 \\
(58)\end{array}$ & $\begin{array}{l}6.71 \\
(47)\end{array}$ & 15 & 16 & 26 \\
\hline BION - 08 & $\begin{array}{l}2.43 \\
(17)\end{array}$ & $\begin{array}{l}5.14 \\
(36)\end{array}$ & $\begin{array}{l}6.57 \\
(46)\end{array}$ & 10 & 8 & 25 \\
\hline BION - 13 & $\begin{array}{l}7.71 \\
(54)\end{array}$ & $\begin{array}{l}7.71 \\
(54)\end{array}$ & $\begin{array}{l}6.57 \\
(46)\end{array}$ & 29 & 12 & 18 \\
\hline BION - 17 & $\begin{array}{l}3.71 \\
(26)\end{array}$ & $\begin{array}{l}5.57 \\
(39)\end{array}$ & $\begin{array}{l}5.57 \\
(39)\end{array}$ & 19 & 18 & 18 \\
\hline BION - 47 & $\begin{array}{l}5.14 \\
(36)\end{array}$ & $\begin{array}{l}4.14 \\
(29)\end{array}$ & $\begin{array}{l}5.14 \\
(36)\end{array}$ & 36 & 15 & 15 \\
\hline BION - 49 & $\begin{array}{l}5.43 \\
(38)\end{array}$ & $\begin{array}{l}5.29 \\
(37)\end{array}$ & $\begin{array}{l}4.71 \\
(33)\end{array}$ & 17 & 23 & 19 \\
\hline BION - 69 & $\begin{array}{l}6.14 \\
(43)\end{array}$ & $\begin{array}{l}6.43 \\
(45)\end{array}$ & $\begin{array}{l}4.86 \\
(34)\end{array}$ & 29 & 17 & 13 \\
\hline Total No. & 243 & 298 & 281 & 155 & 109 & 134 \\
\hline Average No. per primer & 34.7 & 42.6 & 40.1 & 22.1 & 15.6 & 19.1 \\
\hline
\end{tabular}

GS: Gunsan, SA: Shinan, YG: Yeonggwang

in the PCR profiles of five species of Eastern Pacific abalone (genus Haliotis) (Muchmore et al., 1998), the brittle star (Amphiura filiformis) (McCormack et al., 2000), oyster (Kim et al., 2004), Korean catfish (Yoon \& Kim, 2004), Venus clam (Park \& Yoon, 2008) and cockle (Kang \& Yoon, 2013).

The seven oligonucleotides primers BION-01, BION-08, BION-13, BION-17, BION-47, BION-49 and BION-69 were used to produce unique shared loci to each population and shared loci by the three populations, as summarized in Table 4. The oligonucleotides primer BION-13 generated 42 unique loci to each population, approximately $200 \mathrm{bp}$, 400 bp, 800 bp, 900 bp, 1,000 bp and 1,200 bp respectively, in the Shinan population. Remarkably, the primer BION13 detected 42 shared loci by the three populations, major and/or minor fragments of sizes $200 \mathrm{bp}$ and $400 \mathrm{bp}$, respectively, which were identical in all samples. With reference to average bandsharing value (BS) results, individuals from Shinan population (0.811) displayed higher bandsharing values than did individuals from Gunsan population (0.626), as summarized in Table 5. In the present study, the dendrogram gained by the seven oligonucleotides primers highlight three genetic clusters: cluster 1 (GUNSAN $01 \sim$ GUNSAN 07), cluster 2 (SHINAN $08 \sim$ SHINAN 14) and cluster 3 (YEONGGWANG $15 \sim$ YEONGGWANG 21), as shown in Fig. 4. Among the seven white clam individuals the shortest genetic distance that displayed significant molecular differences was between individuals 13 and 14 from the Shinan population (genetic distance $=0.036$ ), while the longest genetic distance among the twenty-one Meretrix lusoria individuals that displayed significant molecular differences was between individuals GUNSAN no. 01 and SHINAN no. 14 (genetic distance $=0.574$ ). Comparatively, individuals of SHINAN population were 
Table 4. The number of unique loci to each population and number of shared loci by the three populations produced by PCR analysis using 7 oligonucleotides primers in Gunsan, Shinan and Yeonggwang population of Meretrix lusoria, respectively

\begin{tabular}{ccccc}
\hline \hline Item & \multicolumn{2}{c}{ No. of unique loci to each population } & No. of shared loci by the three populations \\
\cline { 2 - 5 } Primer $\backslash$ Population & GS & SA & YG & $\begin{array}{c}\text { Three populations } \\
\text { (7 individuals per population) }\end{array}$ \\
\hline BION - 01 & 14 & 42 & 21 & 21 \\
BION - 08 & 7 & 28 & 21 & 0 \\
BION - 13 & 35 & 42 & 28 & 42 \\
BION - 17 & 7 & 21 & 21 & 21 \\
BION - 47 & 0 & 14 & 21 & 0 \\
BION - 49 & 21 & 14 & 14 & 21 \\
BION - 69 & 14 & 28 & 21 & 105 \\
\hline Total no. & 98 & 189 & 147 & 15 \\
\hline Average no. per primer & 14 & 27 & 21 & 0 \\
\hline
\end{tabular}

GS: Gunsan, SA: Shinan, YG: Yeonggwang

Table 5. Manifold comparisons of average bandsharing values among Korean Meretrix lusoria populations from three areas were produced along with the bandsharing values and similarity matrix

\begin{tabular}{cccc}
\hline \hline Populations & GS & SA & YG \\
\hline GS & $0.626 \pm 0.064^{\mathrm{b}}$ & $0.491 \pm 0.056^{\mathrm{a}}$ & $0.482 \pm 0.039^{\mathrm{a}}$ \\
SA & - & $0.811 \pm 0.064^{\mathrm{c}}$ & $0.653 \pm 0.072^{\mathrm{b}}$ \\
YG & - & - & $0.729 \pm 0.064^{\mathrm{bc}}$ \\
\hline
\end{tabular}

$\stackrel{\mathrm{a} \sim \mathrm{c}}{\mathrm{a}}$ Values with different superscript are significantly different, $P<0.05$

Each value is a result of three different experiments.

GS: Gunsan, SA: Shinan, YG: Yeonggwang

fairly closely related to that of YEONGGWANG population. As above mentioned, a dendrogram disclosed close relationships between individual identities within three geographical bivalve populations (McCormack et al., 2000; Kang \& Yoon, 2013). In bivalves, cluster analysis of the pairwise population matrix, created from genetic data, exhibited that geographically close populations have a tendency to cluster together in the blacklip abalone (Huang et al., 2000).

Three Meretrix lusoria populations can be evidently distinguished, by PCR-founded approach. The potential of oligonucleotides amplified polymorphic and/or specific DNAs to identify diagnostic markers, species and population identification in shellfish (Callejas \& Ochando, 1998; McCormack et al., 2000; Park et al., 2008; Kang \& Yoon, 2013) has also been well recognized. PCR fragments discovered in this study may be worthwhile as a DNA marker the three geographical populations to discriminate. In general, the population classification of venerid clam is constructed on morphological variations in shell body weight, shell color, shell height, shell length, shell type and feet length. It is presumed that differences in such characters reflect diverse origins or genetic identity (Chenyambuga et al., 2004). If systematic research of Korean Veneridae is in additive progress, these data could 


\section{Cluster_Tree}

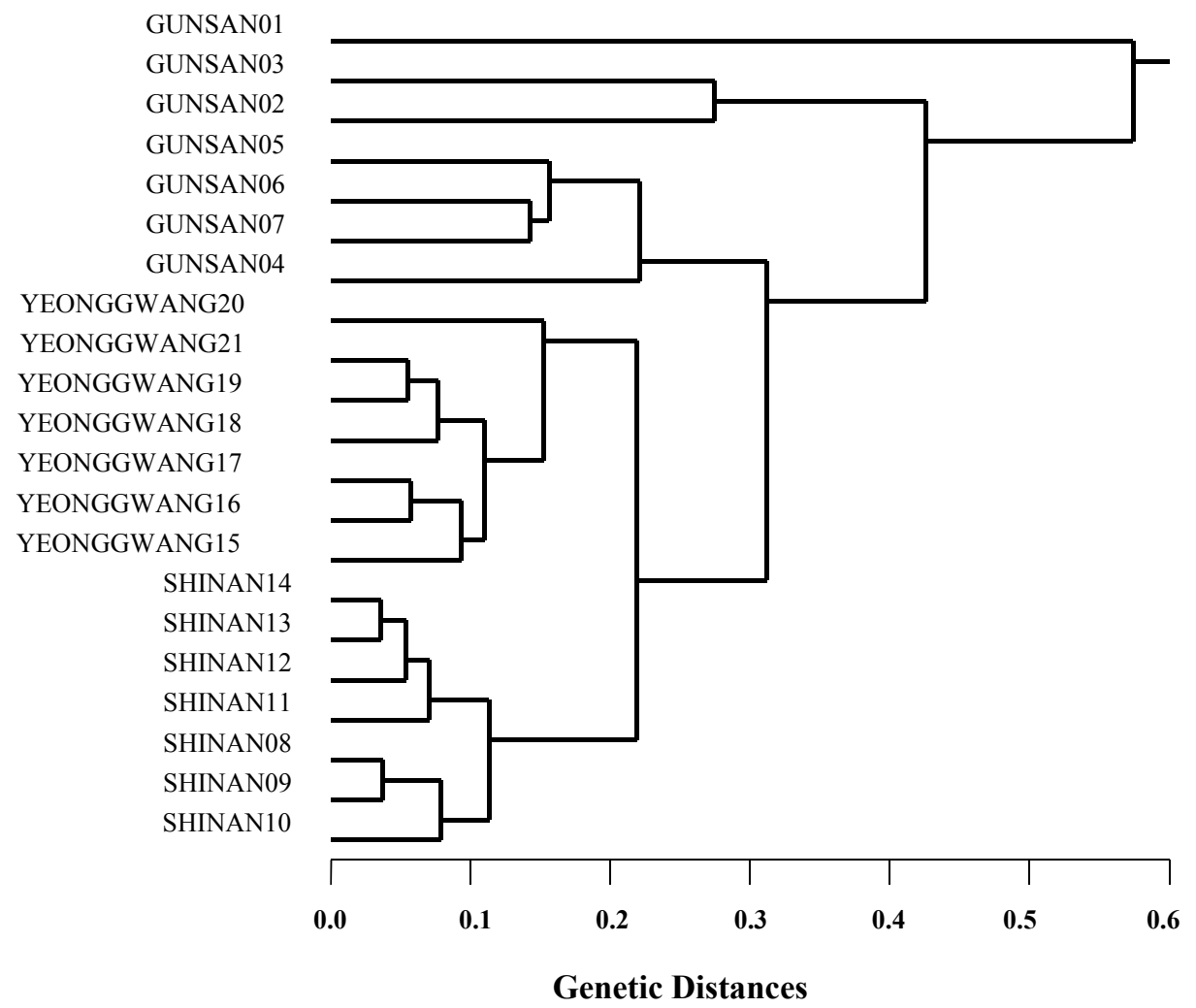

Fig. 4. Hierarchical dendrogram of genetic distances, obtained from three populations of Meretrix lusoria. The relatedness among different individuals in the Meretrix lusoria populations from Gunsan, Shinan and Yeonggwang of the Korean Peninsula were created along with the bandsharing values and similarity matrix.

be used as basic data.

\section{REFERENCES}

Callejas C, Ochando MD (1998) Identification of Spanish barbel species using the RAPD technique. J Fish Biol $53: 208-215$.

Chen AH, Li ZX, Feng GN (2009) Phylogenetic relationships of the genus Meretrix (Mollusca: Veneridae) based on mitochondrial COI gene sequences. Zool Res 30:233-239.

Chenyambuga SW, Hanotte O, Hirbo J, Watts PC, Kemp SJ, Kifaro GC, Gwakisa PS, Petersen PH, Rege JEO (2004) Genetic characterization of indigenous goats of
sub-Saharan Africa using microsatellite DNA markers. Asian-Aust J Anim Sci 17:445-452.

Folmer O, Black M, Hoeh W, Lutz R, Vrijenhoek R (1994) DNA primers for amplification of mitochondrial cytochrome c oxidase subunit I from diverse metazoan invertebrates. Mole Mar Biol Biotechnol 3:294-299.

Huang BX, Peakall R, Hanna PJ (2000) Analysis of genetic structure of blacklip abalone (Haliotis rubra) populations using RAPD, minisatellite and microsatellite markers. Mar Biol 136:207-216.

Jung HT, Kim J, Choi SD (2004) Phylogenetic relationship of the five Korean Veneridae clams, Bivalvia, Veneroida according to morphological characters. J Aquacul 17: 197-208. 
Kang SK, Yoon JM (2013) Geographic variations of three Fulvia mutica populations. Korean J Malacol 29(3): 163-169.

Kim JY, Park CY, Yoon JM (2004) Genetic differences and DNA polymorphism in oyster (Crassostrea spp.) analysed by RAPD-PCR. Korean J Genet 26:123-134.

McCormack GC, Powell R, Keegan B (2000) Comparative analysis of two populations of the brittle star Amphiura filiformis (Echinodermata: Ophiuroidae) with different life history strategies using RAPD markers. Mar Biotechnol 2:100-106.

Min DK, Lee JS, Koh DB, Je JK (2004) Mollusks in Korea. Min Molluscan Research Institutte.

Jeffreys AJ, Morton DB (1987) DNA fingerprints of dogs and cats. Anim Genet 18:1-15.

Muchmore ME, Moy GW, Swanson WJ, Vacquier VD. (1998) Direct sequencing of genomic DNA for characterization of a satellite DNA in five species of Eastern Pacific abalone. Mol Mar Biol Biotechnol 7(1):1-6.
Park GS, Yoon JM (2008) Geographic variations between jedo venus clam (Protothaca jedoensis Lischke) populations of Boryeong and Wonsan of Korea. Korean J Malacol 24:13-26.

Wieckowski MR, Giorgi C, Lebiedzinska M, Duszynski J, Pinton P (2009) Isolation of mitochondria-associated membranes and mitochondria from animal tissues and cells. Nat Prot 4(11):1582-1590.

Yamakawa AY, Imai H (2012) Hybridization between Meretrix lusoria and the alien congeneric species $M$. petechialis in Japan as demonstrated using DNA markers. Aquat Inv 7 Iss 3:327-336.

Yoke-Kqueen C, Radu S (2006) Random amplified polymorphic DNA analysis of genetically modified organisms. J Biotechnol 127:161-166.

Yoon JM, Kim JY (2004) Genetic differences within and between populations of Korean catfish (S. asotus) and bullhead (P. fulvidraco) analysed by RAPD-PCR. AsianAust J Anim Sci 17:1053-1061. 